\title{
ANALISIS UJI PENYERAPAN AIR DAN STRUKTUR MIKRO KOMPOSIT LAMINATE HYBRID SERAT SISAL DAN BATANG PISANG DENGAN MATRIK EPOXY
}

\author{
I Putu Krishna Artha Sastra, Nasmi Herlina Sari, Sujita \\ Jurusan Teknik Mesin, Universitas Mataram \\ Alamat : Jl. Majapahit No. 62. Mataram. 0370-636087
}

\begin{abstract}
The purpose of this study is to investigate and analyze about absorption properties of the composite laminate, microstructure hybrid sisal and banana fiber with epoxy matrix. Composite manufacturing was done by hand lay-up method with a ratio of fiber volume fraction of sisal and banana trunks 0:40, 10:30, 15:25, 20:20, 30:10, 40:0 (\%) With direction of sisalana agave fiber orientation and banana fiber by fiber length according to the mold. Specimen testing was done by the water absorption test with the standard ASTM D571-8.. Test results obtained from the average water absorption properties of composites with the highest ratio of fiber volume fraction of $40 \%: 0 \%$ is $42.4 \%$ while the lowest average water absorption properties contained in the composite with fiber volume fraction of $0 \%: 40 \%$, with percentage of $11.5 \%$. Therefore we can conclude the increasing volume fraction of sisal fiber withidirection of fiber orientation, the lower of water absorption properties and conversely increasing the volume of woven banana fiber orientation, the higher of water absorptionproperties.
\end{abstract}

Keywords: composites, sisalana agave fiber, sheet of banana fiber, volume fraction, water absorption, microstructure

1. Pendahuluan
Komposit merupakan suatu material
didunia teknik yang dibuat dengan penggabungan dua macam bahan yang mempunyai sifat berbeda menjadi satu material baru dengan sifat yang berbeda pula. Komposit dari bahan serat terus diteliti dan dikembangkan guna menjadi bahan alternatif pengganti bahan logam, hal ini disebabkan sifat komposit serat yang lebih kuat dan ringan dibandinggkan dengan logam. Komposit mempunyai keunggulan tersendiri dibandingkan dengan bahan teknik alternatif lain seperti kuat, ringan tahan korosi, ekonomi, dsb (Nasmi Herlina Sari, dkk., 2011).

Penelitian yang mengarah terhadap pengembanggan komposit telah dilakukan, terutama komposit penguat serat alam. Penelitian ini dilakukan seiring dengan majunya eksploitasi penggunaan bahan alam alam dalam kehidupan sehari-hari.Keuntungan mendasar yg dimiliki oleh serat alam adalah jumlah berlimpah, dapat diperbaharui dan di daur ulang serta tidak mencemari lingkungan. Untuk memperoleh sifat mekanik yang tinggi maka serat alam telah diberi berbagai macam perlakuan yang dapat meningkatkan sifat mekaniknya.
Penelitian terdahulu/terkait dengan penelitian ini, seperti yg dilakukan oleh Murherje dan Satyanarayana, 1984. Dimana dalam penelitiannya mereka meneliti serat sisal. Sisal merupakan salah satu serat alam yang paling banyak digunakan dan paling mudah dibudidayakan. Serat sisal merupakan serat keras yang di hasilkan dari proses ekstraksi dari daun tanaman sisal (agave sisalana). Tanaman sisal dapat menghasilkan 200-250 daun dimana masing-masing daun terdiri dari 1000-1200 bundel serat yang mengandung $4 \%$ serat, $0,75 \%$ kultikula, $8 \%$ material kering, $87,25 \%$ air. (Murherjee dan Satyanarayana, 1984).

Selain serat sisal, pemanfaatan serat pisang merupakan langgah yang baik juga guna meninggkatkan fungsinya Pisang (musa spp) adalah tanaman buah yang berasal dari kawasan Asia Tenggara (termasuk Indonesia), tanaman ini kemudian menyebar ke Afrika (Madagaskar), Amerika Selatan dan tengah. Di Jawa Barat, pisang disebut cau sedangkan di Jawa tengah dan Jawa Timur disebut Gedang. Pengembangan riset dan teknologi dengan memanfaatkan produk lokal merupakan langkah bijak guna meningkatkan nilai jual material lokal.(Arif Wicaksono, 2006) 
Berdasarkan uraian yang telah dikemukakan pada latar belakang diatas maka dapat dirumuskan suatu permasalahan yang menjadi objek dalam penelitian ini adalah analisis uji penyerapan air dan struktur mikro komposit laminate hybride serat sisal dan batang pisang dengan matrik epoxy. Pengujian yang dilakukan adalah pengujian struktur mikro, dan uji penyerapan air, dengan menggunakan serat sisal dan pelepah batang pisang yang orientasi serat sisal searah dan pelepah batang pisang karena sesuai dengan struktur alami dari pelepah batang pisang. Fraksi volume serat yang digunakan adalah $0: 40,10: 30,15: 25,20: 20,30: 10,40: 0$ (\%) fraksi volume. Serat-serat tersebut direndam dalam larutan $\mathrm{NaOH} 4 \%$ selama 2 jam, lalu dipotong dengan panjang yang disesuaikan dengan cetakan. Benda uji dibuat dengan cara hand lay up dan dengan penekanan secara manual menggunakan kaca sebagai cetakan dan penekan. Adapun yang menjadi tujuan dalam penelitian ini adalah untuk menganalisis sifat penyerapan air dan struktur mikro komposit laminate hybrid serat sisal / batang pisang bermatrik epoxy.

\section{Dasar Teori}

\subsection{Komposit}

Gabungan antara serat dan matrik disebut bahan komposit. Bahan komposit menggabungkan keunggulan kekuatan dan kekakuan serat dengan massa jenis yang rendah. Hasilnya suatu bahan yang ringan tetapi kuat dan kaku. Dengan kata lain, bahan ini mempunyai harga spesifik modulus dan modulus strength yang lebih besar dibandingkan dengan bahan lain.

Secara umum, dikenal tiga kelompok komposit, yaitu:

1. Komposit berserat yaitu komposit berpenguat serat antara lain seperti, serat gelas (fiber glass), serat karbon, serat grafit sampai serat baja.

2. Komposit laminer atau laminat yaitu komposit berpenguat dalam bentuk lembaran seperti kertas, kain.

3. Komposit partikel atau partikulat yaitu komposit berpenguat dalam bentuk butiran seperti kerikil, pasir, filler dalam bentuk kontinyu.

Pada umumnya bahan komposit terdiri dari dua unsur, yaitu serat (fiber) dan bahan pengikat serat tersebut yang disebut matrik.

1. Serat
Salah satu unsur penyusun bahan komposit adalah serat. Serat inilah yang terutama menentukan karakteristik bahan komposit, seperti kekakuan, kekuatan serta sifat-sifat mekanik lainnya. Serat inilah yang menahan sebagian besar gaya-gaya yang bekerja pada bahan komposit.

2. Matriks (Resin)

Matriks (resin) dalam susunan komposit bertugas melindungi dan mengikat serat agar dapat bekerja dengan baik. Matriks harus bisa meneruskan beban dari luar ke serat.

\subsection{Tanaman Sisal}

Tanaman Sisal yang juga mempunyai nama lain, yaitu Agave sisalana Perrine, pada umumnya termasuk jenis tanaman semusim. Menurut sejarah, tanaman ini berasal dari Brazil dan dibawa ke Indonesia oleh para pelaut Spanyol dan Portugis sekitar tahun 1599.

Tanaman Sisal akan dibongkar setelah dua atau tiga kali panen untuk diganti tanaman baru, oleh karena itu limbah daun Sisal terus berkesinambungan sehingga cukup potensial untuk dimanfaatkan sebagai produk tekstil yang dapat memberikan nilai tambah (Doraiswarmy dkk., 1993).

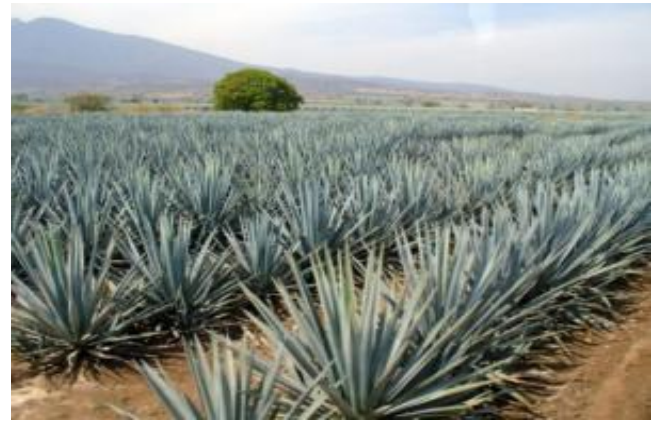

Gambar 2.1 Tanaman Sisal

Karena daun sisal tidak mempunyai tulang daun, adanya serat-serat dalam daun sisal tersebut akan memperkuat daun sisal saat pertumbuhannya Dari berat daun sisal hijau yang masih segar akan dihasilkan kurang lebih sebanyak 2,5 sampai $3,5 \%$ serat serat daun sisal.

\section{,2.3 Tanaman Pisang}

Pisang (musa spp) adalah tanaman buah yang berasal dari kawasan Asia Tenggara (termasuk Indonesia), tanaman ini 
kemudian menyebar ke Afrika (Madagaskar), Amerika Selatan dan tengah. Di Jawa Barat, pisang disebut cau sedangkan di Jawa tengah dan Jawa Timur disebut Gedang. Tanaman ini juga pemanfaatnya belum terlalu maksimal, hanya sebatas dikonsumsi buahnya dan batangnya yang digunakan untuk makanan ternak.

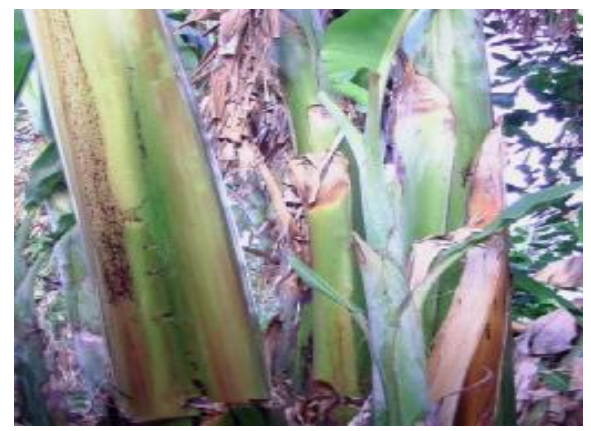

Gambar 2.2 Tanaman Pisang

\section{4. Epoxy}

Perekat ini merupakan produk sintetik termoset dari reaksi resin epoxy dengan zat pengeras. Dapat diperoleh dalam bentuk sistem satu atau dua komponen.Sistem satu komponen meliputi resin cair bebas, larutan, pasta resin cair, bubuk, pellet, dan pasta. Sistem dua komponen terdiri atas resin zat curing yang dicampur saat akan digunakan. Sistem juga mengandung pemlastik, pengecer reaktif, filler, pigmen dan zat resin lain. Pemakaian hardener reaktif atau katalis untuk mendukung curing menyebabkan keluarnya panas. Pada curing suhu kamar perlu hardener tercepat supaya tak memerlukan panas dari luar. Resin epoksi berbentuk cair dengan 2 campuran, satu epoksi herdener, kedua epoksi resin,dengan perbandingan 1:1

\section{Metode Penelitian}

\subsection{Uji Berat Jenis}

Uji berat jenis dilakukan sebelum pengujian penyerapan air dan uji pembengkakan komposit. Berat jenis Komposit laminate diperoleh dengan persamaan berikut :

$$
\rho=\frac{m}{v}
$$

Dimana :

$\rho=$ berat jenis $\left(\mathrm{kg} / \mathrm{m}^{3}\right)$

$$
\begin{aligned}
\mathrm{m} & =\text { berat }(\mathrm{kg}) \\
\mathrm{v} & =\text { volume }\left(\mathrm{m}^{3}\right)
\end{aligned}
$$

\subsection{Uji Penyerapan Air}

Penyerapan air oleh komposi laminate hybrid dilakukan dengan standar ASTM D57188 untuk uji penyerapan air. Komposit ditimbang dengan timbangan digital dengan ketelitian 0,01 gram baik sebelum dan setelah perendaman. Berat jenis komposit diperoleh dengan persamaan berikut :

$$
\left(\frac{m_{1}-m_{0}}{m_{0}}\right) \times 100 \%
$$

Dimana :

mo $=$ berat Awal (gr)

$\mathrm{m} 1$ = berat Akhir (gr)

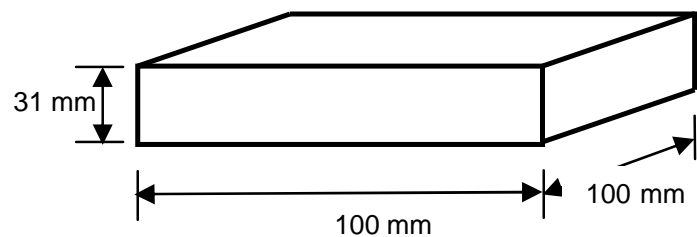

Gambar 3.1 Spesimen Uji Penyerapan air ASTM D 571-88

Spesimen komposit dibuat secara laminate. Ukuran spesimen $100 \mathrm{~mm} \times 100 \mathrm{~mm}$ x $31 \mathrm{~mm}$ yang dibentuk dengan menggunakan cetakan dari kaca yang sudah dilapisi oleh Kit mobil yang berfungsi sebagai pelumas, seperti ditunjukkan dalam gambar 4.1 lalu dilakukan penekanan dengan pemberat sebesar kurang lebih $60 \mathrm{~kg}$ yang bertujuan untuk meminimalkan adanya gelembung udara atau void karena dapat menyebabkan cacat pada komposit tersebut. Setelah Komposit terbentuk sesuai dengan cetakan lalu dlanjutkan dengan Uji penyerapan air yang dilakukan dengan cara perendaman spesimen selama $7 \times 24$ jam seperti pada gambar 3.5. Komposit tersebut ditimbang sebelum dan setelah dilakukan perendaman dengan timbangan digital dengan ketelitian 0,01 gram. 


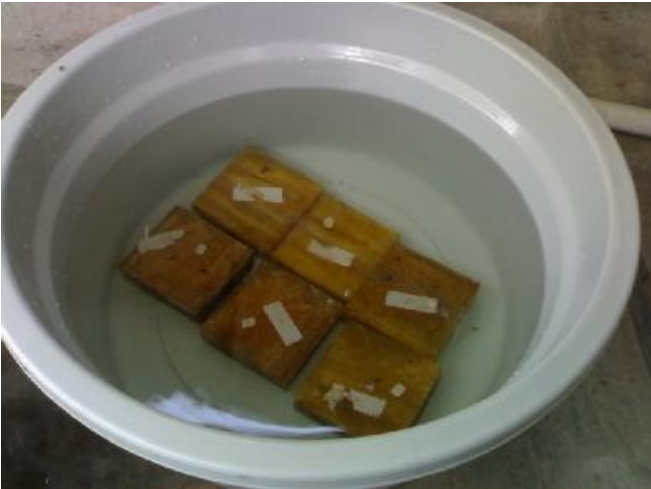

Gambar 3.2 Proses perendaman specimen komposit

\subsection{Uji Pembengkakan Komposit}

Uji pembengkakan komposit dilakukan setelah direndam di dalam air (swelling in water). Spesimen ini direndam tenggelam di dalam air selama $7 \times 24$ jam. Swelling diperoleh dengan membagi selisih volume spesimen sesudah perendam dan sebelum direndam dalam air dibagi dengan volume sebelum perendaman dalam air dikalikan 100\%. Volume komposit diukur dengan mengukur panjang, lebar, tebal komposit dengan jangka sorong dan kemudian dikalikan ketiga panjang sisi tersebut. Berat jenis komposit diperoleh dengan persamaan berikut :

$$
\left(\frac{v_{1}-v_{0}}{v_{0}}\right) \times 100 \%
$$

Dimana :

$$
\begin{array}{ll}
\mathrm{v}_{0} & =\text { Volume Awal }\left(\mathrm{mm}^{3}\right) \\
\mathrm{v}_{1} & =\text { Volume Akhir }\left(\mathrm{mm}^{3}\right)
\end{array}
$$

\subsection{Uji Struktur Mikro}

Penelitian ini menggunakan mikroskop cahaya, adapun manfaat dari pengamatn struktur mikro ini adalah :

1. Mempelajari hubungan antara sifat-sifat dengan struktur dan cacat pada spesimen

2. Memperkirakan sifat bahan jika hubungan tersebut sudah diketahui

Persiapan yang harus dilakukan sebelum mengamati struktur mikro adalah pemotongan spesimen, pengampelasan dan pemolesan dilanjutkan pengetsaan.

\subsection{Pengujian Struktur makro}

Pada pengujian struktur makro, cara kerjanya sama dengan struktur mikro. Hanya saja pengujian ini dilakukan pada saat setelah spesimen dilakukan perendaman. Pengujian struktur makro dilakukan untuk mengetahui jenis penyerapan air yang terjadi,

\subsection{Teknik Pengolahan Data}

Data yang diperoleh juga dianalisis dengan metode statistik yaitu metode one way analysis of varians.

Dalam penelitian ini digunakan cara perhitungan dengan menggunakan persamaan-persamaan sebagai berikut :

- $S_{T} \quad=\sum_{i=1}^{3} \sum_{j=1}^{3} y_{i j}^{2}-\frac{y,,^{2}}{N}$

- $\quad S_{\text {Treatments }}=\frac{1}{n} \sum_{j=1}^{3} y_{i}^{2}-\frac{y,,^{2}}{N}$

- $S S_{E} \quad=S S_{T}-S S_{\text {Treatments }}$

- $M S_{\text {Treatmen }}=\frac{S S_{\text {Treatment }}}{a-1}$

- $M S_{E} \quad=\frac{S S_{E}}{N-1}$

Jika nilai $F_{\text {hitung }}>F_{\text {tabel }}$ berarti $\mathrm{H}_{0}$ ditolak sehingga pengaruh signifikan terhadap uji penyerapan air. Jika nilai $F_{\text {hitung }}<F_{\text {tabel }}$ berarti $\mathrm{H}_{0}$ diterima sehingga tidak berpengaruh signifikan terhadap uji penyerapan air (Montgomery, 2001).

Table 3.1 Analysis of varians

\begin{tabular}{|c|c|c|c|c|c|}
\hline $\begin{array}{c}\text { Source of } \\
\text { Variation }\end{array}$ & $\begin{array}{c}\text { Sum of } \\
\text { Squares }\end{array}$ & $\begin{array}{c}\text { Degree of } \\
\text { Freedom }\end{array}$ & $\begin{array}{c}\text { Mean } \\
\text { Squares }\end{array}$ & $\mathrm{F}_{0}$ & $\begin{array}{c}\text { F table } \\
\alpha=0,05\end{array}$ \\
\hline $\begin{array}{c}\text { Fraksi } \\
\text { volume } \\
\text { filler }\end{array}$ & $S S_{\text {Treatment }}$ & $a-1$ & $M S_{\text {Treatment }}$ & $F_{0}=\frac{M S_{\text {Treatment }}}{M S_{E}}$ & $F \alpha(3,89)$ \\
\hline Error & $S S_{E}$ & $N-a$ & $M S_{E}$ & & \\
\hline Total & $S S_{T}$ & $N-1$ & & & \\
\hline
\end{tabular}

\section{Hasil Dan Pembahasan}

\subsection{Uji Photo Micro Lab}

Proses pengamatan mikrostruktur menggunakan uji photo mikro lab dilakukan pada elemen-elemen yang ada pada komposit dilakukan pada titik pengamatan pada daerah matrik, interface matrik penguat, dan pada daerah penguat. Setelah permukaan komposit tersebut dipoles dengan autosol. Struktur mikro dari komposit dapat dapat memberikan sebagian informasi yang mendukung sifat dari komposit tersebut. Adapun hasil struktur mikro 
yang dihasilkan dari pengamatan metalografi yang dilakukan sebagai berikut :

1. Sisal $0 \%$ : Pisang $40 \%$

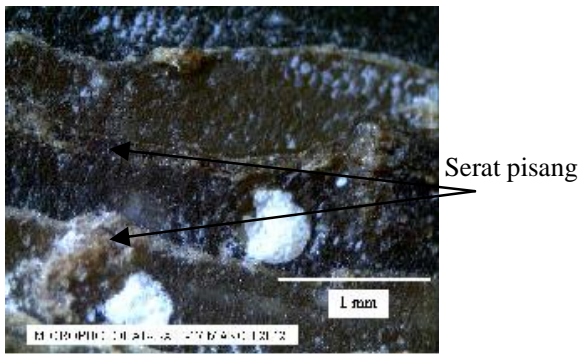

Gambar 4.1 Foto Mikro Spesimen penyerapan air dengan fraksi volume serat sisal $40 \%$ dan serat pisang $0 \%$ (40\%:0\%).

Pada pengamatan struktur Mikro Spesimen Penyerapan air dengan fraksi volume serat sisal Sisal 0\% : Pisang 40\% (0\%:40\%) terlihat bahwa serat pisang paling mendominasi, namun terlihat juga adanya void (lubang udara) yang terjadi pada komposit tersebut, sehingga menyebabkan adanya bubuk resin yang terjebak pada void tersebut.

\section{Sisal $10 \%$ : Pisang $30 \%$}

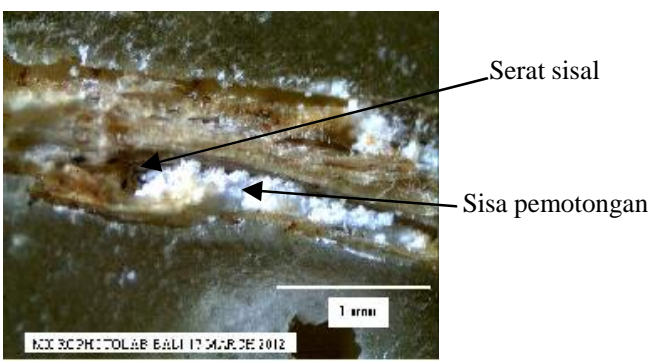

Gambar 4.2 Foto Mikro Spesimen

Penyerapan air dengan fraksi volume serat Sisal $10 \%$ : Pisang $30 \%$

Pada pengamatan struktur mikro spesimen komposit dengan fraksi volume serat sisal Sisal 10\% : Pisang 30\% (10\%:30\%) seperti pada gambar di atas, mikrostruktur kompositnya lebih renggang karena adanya penambahan jumlah persentase serat batang pisang karena serat batang pisang memiliki diameter dan bentuk yang lebih besar serta orientasi yang berbeda, selain itu juga terdapat sisa pemotongan yang berupa bubuk resin pada spesimen komposit yang dihasilkan pada saat komposit dipotong dengan gerinda potong yang bertujuan untuk memastikan adanya serat pada komposit yang berinteraksi langsung dengan alam (air).
3. Sisal $15 \%$ : Pisang $25 \%$

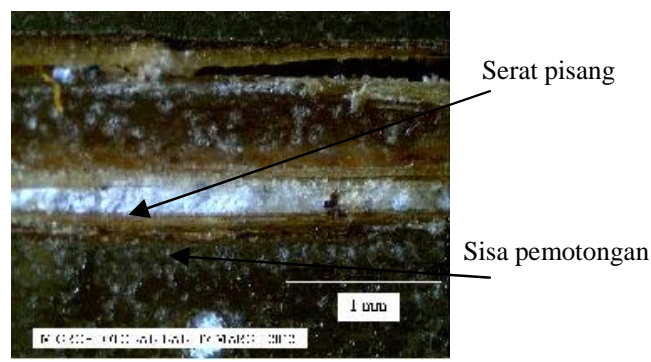

Gambar 4.3 Foto Mikro Spesimen

Penyerapan air dengan fraksi volume serat Sisal 15\% : Pisang 15\% (15\%:15\%)

Pada pengamatan struktur mikro speimen komposit dengan fraksi volume serat sisal 15\% : Pisang 15\% (15\%:15\%) pada gambar di atas mikrostruktur terlihat agak renggang, hal ini dikarenakan proses penekanan yang kurang kuat terutama pada serat pisang yang memiliki ukuran agak besar sehingga bubuk resin lebih banyak banyak terjebak pada bagian rongga tersebut.

\section{Sisal $20 \%$ : Pisang $20 \%$}

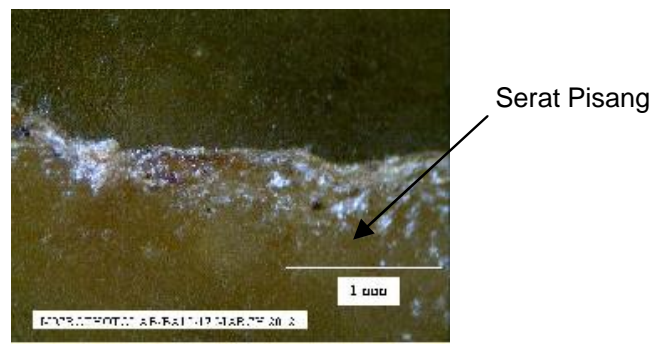

Gambar 4.4 Foto Mikro Spesimen

Penyerapan air dengan fraksi volume serat Sisal 20\% : Pisang 20\% (20\%:20\%)

Pada pengamatan komposit dengan fraksi volume serat sisal $20 \%$ : Pisang $20 \%$, terlihat serat Pisang lebih mendominasi, hal ini terjadi jarena orientasi serat pisang yang berupa anyaman sehingga ukuran dari serat tersebut lebih besar dan lebih terlihat dari serat Sisal dan resin yang agak gelap karena kurangnya pengamplasan dengan autosol 
5. Sisal $30 \%$ : Pisang $10 \%$

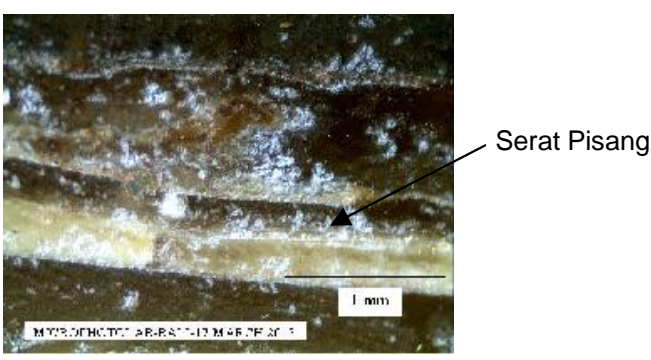

Gambar 4.5 Foto Mikro Spesimen

Penyerapan air dengan fraksi volume serat Sisal 30\% : Pisang 10\% (30\%:10\%)

Pada gambar 4.5 untuk pengamatan spesimen komposit dengan fraksi volume serat Sisal 30\% : serat pisang 10\% terlihat adanya serat pisang yang bertumpuk-tumpuk, dengan ukuran serta jumlah serat yang lebih besar dari pada serat sisal

\section{Sisal $40 \%$ : Pisang $0 \%$}

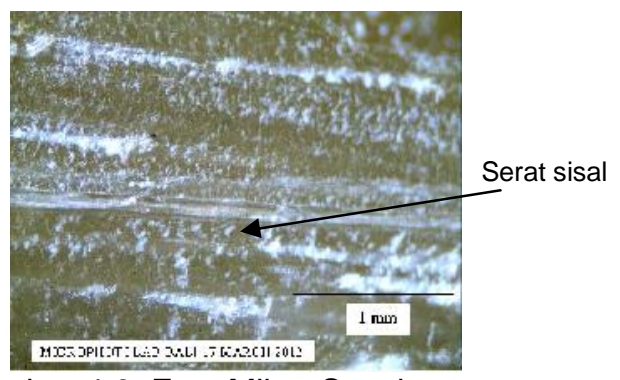

Gambar 4.6 Foto Mikro Spesimen

Penyerapan air dengan fraksi volume

serat Sisal 0\% : Pisang 40\% (0\%:40\%)

Dari pengamatan struktur mikro spesimen dengan fraksi volume serat sisal $40 \%$ dan serat pisang 0\% (40\%:0\%) seperti pada gambar 4.1, struktur komposit tampak jelas serat sisal lebih banyak mendominasi karena jumlah fraksi folume serat sisal sebanyak $40 \%$, namun serat-serat tersebut kelihatan lebih menyatu satu dengan yang lain karena diakibatkan oleh proses penekanan.

\subsection{Hasil uji Penyerapan Air}

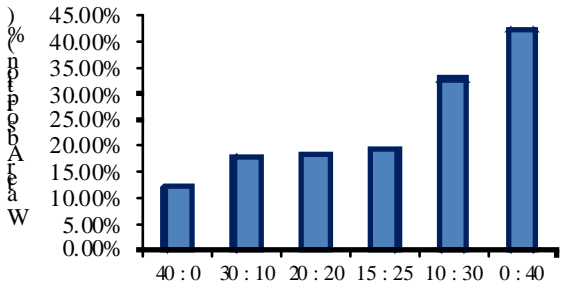

Perbedaan penyerapan air yang terjadi pada komposit laminate hybrid berdasarkan fraksi volume serat sisal dan batang pisang, dapat dilihat dengan jelas bahwa penyerapan air yang paling banyak terjadi terdapat pada spesimen komposit yang mengandung $0 \%$ serat sial : $40 \%$ serat pisang dengan orientasi anyam yaitu sebesar $42,48 \%$ sementara spesimen yang mengandung $40 \%$ serat sisal : $0 \%$ serat pisang dengan orientasi searah mempunyai nilai penyerapan air yang paling kecil yaitu sebesar $12,16 \%$. Penyerapan air pada spesimen ditandai dengan bertambahnya berat spesimen akibat perendaman, selama pengujian,

\subsection{Hasil Uji Struktur Makro}

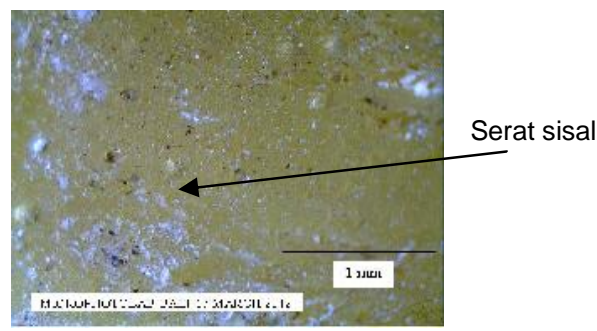

Gambar 4.7 Foto Makro Spesimen penyerapan air dengan fraksi volume serat sisal $40 \%$ dan serat pisang $0 \%(40 \%: 0 \%)$

Seperti gambar 4.7, terlihat jelas pengaruh air terhadap spesimen komposit mulai dari penampakan serat yang tidak terlalu jelas yang diakibatkan karena pada saat proses perendaman, air yang masuk ke dalam komposit menyebabkan serat-serat yang terkandung dalam komposit tersebut mengeluarkan zat-zat warna (pigmen) yang lalu tercampur dengan air, sehingga karena adanya zat tersebut proses pengamatan serat jadi tidak terlalu jelas, serta void yg terlihat semakin jelas karena diisi oleh air.

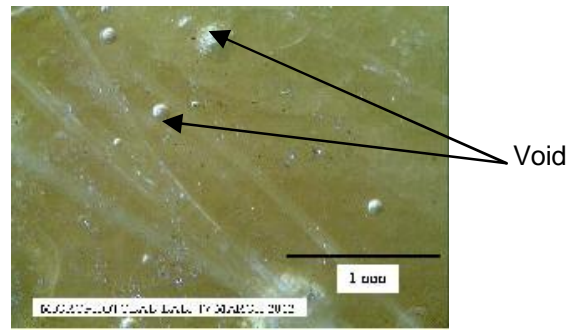

Gambar 4.8 Foto Makro Spesimen

penyerapan air dengan fraksi volume serat sisal 30\% dan serat pisang 10\% (30\% : 10\%) 
Pada gambar 4.8, pengamatan pada spesimen komposit dengan fraksi volume serat Sisal $30 \%$ : Pisang $10 \%$, agak terlihat jelas serat pisang dan sisal yang merupakan komposisi dari spesimen tersebut, selain itu terdapat pula void yang jelas terlihat akibat pengaruh air yang masuk ke dalam komposit tersebut.

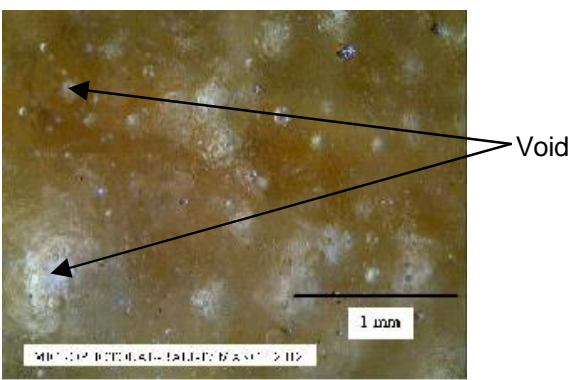

Gambar 4.9 Foto Mikro Spesimen penyerapan air dengan fraksi volume serat sisal $20 \%$ dan serat pisang $20 \%$ (20\%: $20 \%)$

Tidak menutup kemungkinan serat sisal juga banyak menyerap air terutama apabila orientasi serat searah dan anyam (untuk serat pisang) digabungkan dengan komposisi yang lumayan besar yaitu $40 \%$ pada suatu komposit, hal ini mungkin terjadi karena jarak antara serat sisal dan pisang yang sangat kecil lalu mempermudah proses pendistribusian air terjadi antara serat yang satu dengan yang lain serta dengan resin.

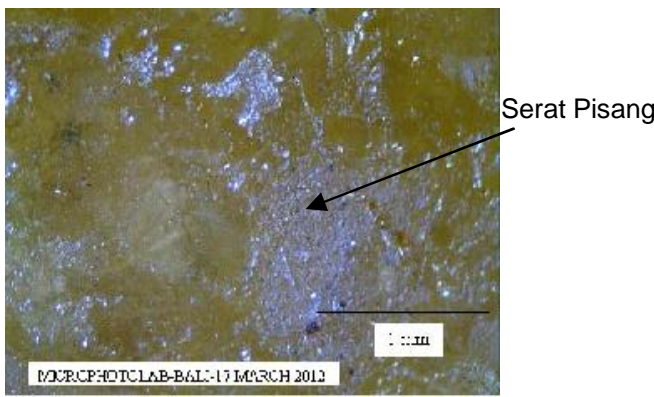

Gambar 4.10 Foto Makro Spesimen

penyerapan air dengan fraksi volume serat sisal $15 \%$ dan serat pisang $25 \%$ (15\%: $25 \%)$

Pada pengamatan komposit dengan fraksi volume serat Sisal 15\% : Pisang $25 \%$, yang tampak pada permukaan hanyalah resin dan tidak tampak adanya serat, hal ini disebabkan karena adanya zat-zat warna (pigmen) yang lalu tercampur dengan air, sehingga karena adanya zat tersebut proses pengamatan serat jadi tidak terlalu jelas.

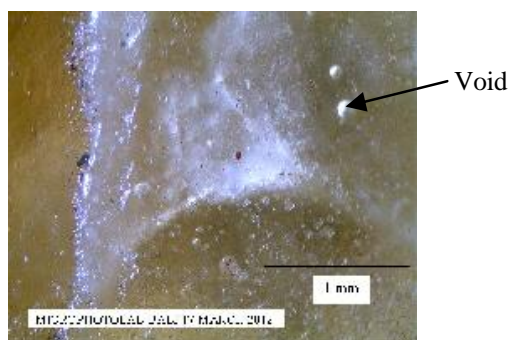

Gambar 4.11 Foto Makro Spesimen penyerapan air dengan fraksi volume serat sisal $10 \%$ dan serat pisang $30 \%$ (10\%: $30 \%)$

Dari gambar 4.6 terlihat bahwa pada permukaan spesimen komposit spesimen penyerapan air dengan fraksi volume Sisal $10 \%$ : Pisang $30 \%$, serat pisang terlihat lebih dominan karena pengaruh fraksi volume dan ukurannya menjadi lebih besar karena banyak mengandung air dan void yang kembali terlihat jelas akibat diisi oleh air.

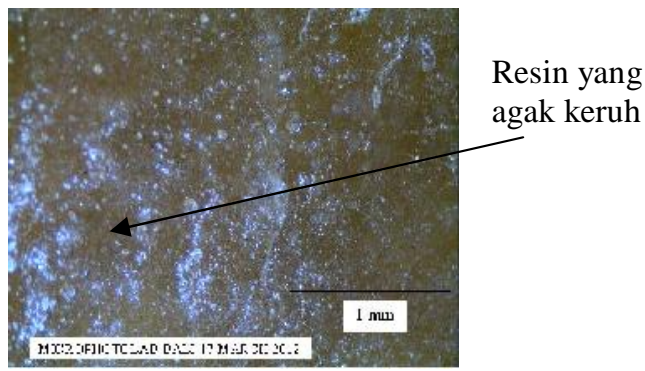

Gambar 4.12 Foto Mikro Spesimen

penyerapan air dengan fraksi volume serat sisal $0 \%$ dan serat pisang $40 \%$ (0\% : 40\%)

Kecenderungan besarnya penyerapan air pada spesimen dikarenakan serat batang pisang mempunyai nilai penyerapan air yang tinggi kemungkinan disebabkan oleh orientasi serat yang berupa anyaman sehingga interaksi antara serat yang satu dengan serat yang lain lebih besar dan menyebabkan proses distribusi air pada masing-masing serat lebih besar jika dibandingkan dengan serat sisal yang orientasinya searah.

\subsection{Hasil Uji Pembengkakan Komposit}

Hubungan antara perbandingan fraksi volume serat dengan sifat pembengkakan komposit dari hasil pengujian didapatkan data seperti yang ditampilkan 


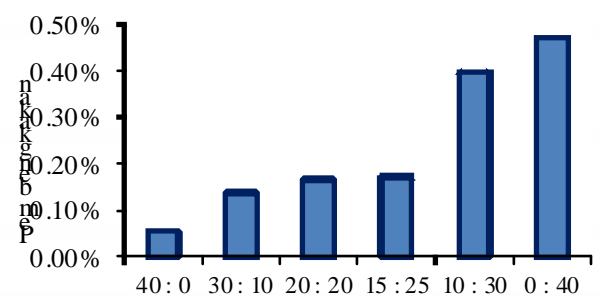

Komposit laminat hybrid serat sisal dan batang pisang mengalami pembengkakan ketika dilakukan perendaman, dimana pembengkakan komposit tertinggi terdapat pada variasi fraksi volume serat sisal dan batang pisang 0:40 (\%) yaitu sebesar 0,47\%, sedangkan pembengkakan komposit terendah terdapat pada variasi fraksi volume serat 40:0 (\%) yaitu sebesar 0,05\%. Dari grafik 4.14 kecenderungan terjadinya pembengkakan komposit laminate hybrid serat sisal dan batang pisang mengalami kenaikan dikarenakan air yang masuk ke dalam komposit dengan arah serat searah pada serat sisal mempunyai nilai terendah akibat air yang masuk ke dalam komposit melalui serat tidak terlalu banyak berinteraksi antara serat yang satu dengan serat yang lain hal ini dapat ditunjukkan pada gambar 4.1, sedangkan serat dengan orientasi anyam mengalami nilai pembengkakan yang paling tinggi karena pada proses anyam adanya interaksi antara serat yang satu dengan serat yang lain sehingga proses pendistribusian air antara serat dan resin menjadi semakin banyak, hal ini dapat ditunjukkan pada gambar 4.13. Perbedaan jenis serat penguat pada komposit mempengaruhi tingkat pembengkakan pada komposit, dimana komposit dengan penguat serat pisang lebih tinggi dibandingkan dengan serat sisal.
4.5 Analysis Of Varians Uji Penyerapan Air Tabel 4.1 Data uji penyerapan air komposit laminate hybrid serat sisal dan batang pisang

\begin{tabular}{|l|l|l|l|l|l|}
\hline \multirow{2}{*}{$\begin{array}{c}\text { Fraksi Volume } \\
\text { Serat } \\
\text { Sisal/Pisang }\end{array}$} & 1 & 2 & 3 & Total Yi & $\frac{3}{y i}$ \\
\cline { 2 - 5 } & 11,54 & 11,45 & 13,50 & 36,49 & 12,16 \\
$30 \%: 0 \%$ & 17,51 & 18,71 & 17,39 & 53,61 & 17,87 \\
$30 \%: 10 \%$ & 17,18 & 18,21 & 19,26 & 54,65 & 18,45 \\
$20 \%: 20 \%$ & 18,77 & 18,52 & 20,47 & 57,76 & 19,25 \\
$15 \%: 25 \%$ & 32,33 & 32,31 & 34,17 & 98,81 & 32,93 \\
$10 \%: 30 \%$ & 42,48 & 42,47 & 42,51 & 127,46 & 42,48 \\
$0 \%: 40 \%$ & $y,,=428,78$ & $\overline{y,}=143,14$ & & \\
\hline
\end{tabular}

Berdasarkan tabel 4.1 setelah perhitungan Rata-rata Uji Penyerapan air maka didapatkan data sebagai berikut:

Tabel 4.2 Analysis Of Varians spesimen komposit laminate hybrid serat sisal dan batang pisang

\begin{tabular}{|c|c|c|c|c|c|}
\hline $\begin{array}{c}\text { Source of } \\
\text { Variation }\end{array}$ & $\begin{array}{c}\text { Sum of } \\
\text { Squares }\end{array}$ & $\begin{array}{c}\text { Degree of } \\
\text { Freedom }\end{array}$ & $\begin{array}{c}\text { Mean } \\
\text { Squares }\end{array}$ & Fo & F tabel \\
\hline $\begin{array}{c}\text { Fraksi volume } \\
\text { serat }\end{array}$ & 1965,2706 & 2 & 982,63 & 1600,087 & 3,89 \\
\hline Error & 10,44 & 16 & 0,6141 & & \\
\hline Total & 1975,71798 & 18 & & & \\
\hline
\end{tabular}

Ditunjukkan bahwa $F_{\text {hitung }}>F_{\text {tabel }}$, yaitu $1600,087>3,89$, maka Ho ditolak. Sehingga variasi fraksi volume serat sisal dan batang pisang berpengaruh signifikan terhadap sifat penyerapan air komposit laminate hybrid serat sisal dan batang pisang dengan matrik epoxy.

\section{Kesimpulan}

Sifat penyerapan air komposit tertinggi terdapat pada spesimen dengan variasi fraksi volume serat pisang $40 \%$ : serat sisal $0 \%$ yaitu rata-rata sebesar $42,4 \%$ dan terendah pada spesimen dengan variasi fraksi volume serat pisang $0 \%$ : serat sisal $40 \%$ yaitu rata-rata sebesar $11,5 \%$. Pertambahan pembengkakan air komposit laminate hybrid tertinggi terdapat pada spesimen dengan variasi fraksi volume serat pisang $40 \%$ : serat sisal $0 \%$ yaitu ratarata sebesar $0,47 \%$ dan terendah pada spesimen dengan fraksi volume serat pisang $0 \%$ : serat sisal $40 \%$ yaitu rata-rata sebesar $0,05 \%$. Dari foto mikro yang telah dilakukan menunjukkan morfologi antara serat dan resin yang terikat dalam suatu hubungan interface yang cukup kuat. 


\section{Daftar Pustaka}

Murherjee dan Satyanarayan (dalam Adhi Kusumastuti, 2009, Aplikasi Serat Sisal Sebagai Komposit Polimer, Universitas Negeri Semarang).

Arif Wicaksono, 2006 (dalam Adhi Kusumastuti, 2009, Aplikasi Serat Sisal Sebagai Komposit Polimer, Universitas Negeri Semarang).

Adhi Kusumastuti, 2009, Aplikasi Serat Sisal Sebagai Komposit Polimer, Universitas Negeri Semarang.

Sulistijono (2008) analisa pengaruh fraksi volume serat kelapa pada komposit matriks polyester terhadap kekuatan tarik, impact dan bending

Surdia,T., 2000, Pengetahuan Bahan Teknik, Jakarta: Pradnya Paramita.

Schwartz M. (1984) Composite Materials Handbook, McGraw-Hill Inc.,NewYork, USA

Justus Kimia Raya. (2001) Technical Data

Sheet, Jakarta.

Hartomo, A. J. Rusdiharsono, A. Hardjanto, D. 1992. Memahami Polimer Dan Perekat, Andi Offset Yogyakarta.

ASTM, 1990, Standards and Literature References for Composite Materials, $2 \mathrm{~d}$ ed., American Society for Testing and Materials, Philadelphia, PA.
Budinski, Kenneth, 2000, Engineering Materials Properties and Selection sixth Edition, Prentice Hall, New Jersey.

Diharjo K. \& Triyono T. (2000) Material Teknik, Buku Pegangan Kuliah, UNS Press, Surakarta

Http://www.iptek.net.id/ind/pd tanobat/view.ph p?mnu=2\&id $=124$

Http://www.estane.com/ind/view.php

Justus Kimia Raya. (2001) Technical Data

Sheet, Jakarta.

Kirby, (1963)strong, fine and silky fibr.

Matthews, F.L., Rawlings, RD., 1993, Composite Material Engineering And Science, Imperial College Of Science, Teknology And Medicine, London, UK.

Nasmi Herlina Sari, Sinarep, Ahmad, IGNK Yudhyadi.(2011) Ketahanan Bending Komposit Hybrid Serat Batang Kelapa/Serat Gelas dengan Matrik Urea Formaldehyde.

Purboputro, P. 2005, Pengaruh Panjang Serat Terhadap Kekuatan Impak Komposit Enceng Gondok Dengan Matrik Polyester, Tugas Akhir Jurusan Teknik Mesin, Universitas Muhamadiah Surakarta, Karta. 